\title{
Hydrogeochemical characteristic of mud volcanism manifestations on Sakhalin Island
}

\author{
Olga A. Nikitenko* \\ Valery V. Ershov
}

\author{
Institute of Marine Geology and Geophysics, FEB RAS, Yuzhno- \\ Sakhalinsk, Russia
}

*E-mail: nikitenko.olga@list.ru

\begin{abstract}
RUS }}$
There are four areas of mud volcanism traditionally set off on Sakhalin Island. Each of them is characterized by one or more eruptive mudflow seepage domains of different morphology. This article considers the results of a study of regional features of the chemical and isotopic $\left(\delta^{18} \mathrm{O}\right.$ and $\delta \mathrm{D})$ composition of groundwater discharging from all known mud volcanoes in the region. A pooled analysis of available literature data showed the studied waters to be heterogeneous in their geochemical parameters. This heterogeneity is most significantly manifested for the total mineralization, which average values vary from 0.1 to $22.5 \mathrm{~g} / \mathrm{l}$ in the waters of different mud volcanic seepage domains. Mud volcanic waters in the region are also represented by different hydrochemical types, but $\mathrm{HCO}_{3}-\mathrm{Cl}-\mathrm{Na}$ waters are the most common. The isotopic characteristics testify the waters of the South Sakhalin, Pugachev, and Vostochny mud volcanoes to be formed as a result of mixing the original sea waters buried under sedimentation with meteoric and dehydration waters. One of the key factors in the metamorphization of these waters is the influx of large amounts of $\mathrm{CO}_{2}$ into the channels of mud volcanoes, which contributes to more intensive leaching of aluminosilicate water-bearing rocks and leads to an increase in the content of $\mathrm{Na}^{+}$and $\mathrm{Mg}_{2}{ }^{+}$in mud volcanic waters. By the pooled geology and geochemical data, we made an assumption that the waters of Daginsky and Lesnovsky mud volcanic manifestations do not refer to mature groundwaters of deep circulation, thus being not generally typical for mud volcanoes. Waterformation temperatures of the South Sakhalin, Pugachev, and Vostochnyy mud volcanoes calculated using the $\mathrm{Mg}-\mathrm{Li}$ hydrochemical geothermometer vary from 51 to $105{ }^{\circ} \mathrm{C}$, which corresponds to depths range from 1.3 to $2.6 \mathrm{~km}$. Water-formation temperatures of the Daginsky thermal and mineral springs calculated using the $\mathrm{K}-\mathrm{Mg}$ geothermometer average $70{ }^{\circ} \mathrm{C}$, which corresponds to the occurrence of an aquifer feeding this fluid system at a depth of $2.1 \mathrm{~km}$.
\end{abstract}

\section{Keywords}

mud volcanoes, groundwater, chemical composition, stable isotopes, water-rock-gas interaction, Sakhalin Island

For citation: Nikitenko O.A., Ershov V.V. Hydrogeochemical characteristic of mud volcanism manifestations on Sakhalin Island. Geosistemy perehodnykh zon = Geosystems of Transition Zones, 2020, vol. 4, no. 3, pp. 321-350. (In Russ. \& Engl.). https://doi.org/10.30730/gtrz.2020.4.3.321-335.336-350

Для цитирования: Никитенко О.А., Ершов В.В. Гидрогеохимическая характеристика проявлений грязевого вулканизма на острове Сахалин. Геосистемы переходных зон, 2020, т. 4, № 3, с. 321-350. 


\section{References}

1. Aliev Ad.A., Guliev I.S., Dadashev F.G., Rakhmanov R.R. 2015. Atlas gryazevykh vulkanov mira [Atlas of the world mud volcanoes]. Baku: Nafta-Press, 322 p. (In Russ.).

2. Chelnokov G.A., Zharkov R.V., Bragin I.V., Veselov O.V., Kharitonova N.A., Shakirov R.B. 2015. Geochemical characteristics of subterranean fluids of the Southern Central Sakhalin Fault. Tikhookeanskaya geologiya = Pacific Geology, 34(5): 81-95. (In Russ., abstract in Eng.).

3. Chernyshevskaya Z.A. 1958. [On mud volcanoes of the southern part of Sakhalin]. Trudy SakhKNII SO AN SSSR [Transactions of the Sakhalin Complex Scientific Research Institute SB AS of USSR], 6: 118-130. (In Russ.).

4. Driver Dzh. 1985. Geokhimiya prirodnykh vod. Moscow: Mir, 440 p. Transl. from J.I. Drever. The Geochemistry of Natural Waters: Surface and Groundwater Environments. 1982.

5. Ershov V.V. 2017. [Peculiarities of substance composition in products of the Pugachev mud volcano activity (Sakhalin Island)]. In.: Stroyeniye litosfery i geodinamika: Materialy XXVII Vseros. molodezhnoy konf. c uchastiyem issledovateley iz drugikh stran, 22-28 maya 2017, Irkutsk [Structure of lithosphere and geodynamics: Proceedings of the XXVII All-Russian conference for young researchers with the participation of researchers from other countries, May 22 28, 2017, Irkutsk]. Irkutsk: Inst. of the Earth Crust SB RAS, 88-89. (In Russ.).

6. Ershov V.V. 2018. [Isotopic and chemical composition of the waters from the Vostochny mud volcano (Sakhalin Island)]. In.: Geologicheskaya evolyutsiya vzaimodeystviya vody s gornymi porodami: Materialy tret'yey Vseros. nauch. konf. s mezhdunar. uchastiyem, 20-25 avg. 2018, Chita [Geological evolution of water-rock interaction: Proceedings of the third All-Russian scientific conference with international participation, August 20-25, 2918, Chita]. Ulan-Ude: BNTs SB RAN Publ., 284-287. (In Russ.).

7. Ershov V.V., Bondarenko D.D. 2020. Characterization of isotopic and chemical composition of gases ejected from mud volcanoes in different regions of the world. Geoekologiya. Inzhenernaya geologiya. Gidrogeologiya. Geokriologiya [Geoecology. Engineering geology. Hydrogeology. Geokryology], 3: 23-35. (In Russ., abstract in Eng.). http://dx.doi.org/10.31857/S0869780920030029

8. Ershov V.V., Mel'nikov O.A. 2007. Unusual eruption of the Main Pugachevo gas-water-lithoclastic (mud) volcano in Sakhalin during the winter of 2005. Russian J. of Pacific Geology, 1(4): 366-370.

9. Ershov V.V., Nikitenko O.A. 2017. Isotopic and chemical composition of waters of the Yuzhno-Sakhalinsk mud volcano (sampling in 2009 and 2010). Izv. vuzov. Severo-Kavkazskiy region. Yestestvennye nauki = Izv. vuzov. Severo-Kavkazskii Region. Natural Science, 4-1: 110-120. (In Russ., abstract in Eng.). https://doi.org/10.23683/03213005-2017-4-1-110-120

10. [Geology of the USSR]. Vol. 32. [Sakhalin Island. Geological description]. 1970. Moscow: Nedra, 432 p. (In Russ.).

11. Giggenbach W.F. 1988. Geothermal solute equilibria. Derivation of Na-K-Mg-Ca geoindicators. Geochimica et Cosmochimica Acta, 52(12): 2749-2765. https://doi.org/10.1016/0016-7037(88)90143-3

12. Hensen C., Wallmann K., Schmidt M., Ranero C.R., Suess E. 2004. Fluid expulsion related to mud extrusion off Costa Rica - A window to the subducting slab. Geology, 32(3): 201-204.

13. [Hydrogeology of the USSR]. Vol. 34. [Sakhalin Island]. 1972. Moscow: Nedra, 344 p. (In Russ.).

14. Il'yev A.Ya., Saprygin S.M., Siryk I.M. 1970. [Eruption of the Pugachev mud volcano in 1967]. Izvestiya Sakhalinskogo otdela Geograficheskogo obshchestva SSSR [Bulletin of the Sakhalin Department of USSR Geographical society], 1: 92-99. (In Russ.).

15. Kamenev P.A., Zabolotin A.E., Degtyarev V.A., Zherdeva O.A. 2019. Geomechanical model of South Sakhalin active fault. Geosistemy perehodnykh zon = Geosystems of Transition Zones, 3(3): 287-295. (In Russ., abstract in Eng.). https://doi.org/10.30730/2541-8912.2019.3.3.287-295

16. Kharaka Y.K., Mariner R.H. 1989. Chemical geothermometers and their application to formation waters from sedimentary basins. In: Thermal History of Sedimentary Basins, Methods and Case Histories. New York, Springer, 99-117. https://doi.org/10.1007/978-1-4612-3492-0_6

17. Liu C.C., Jean J.S., Nath B., Lee M.K., Hor L.I., Lin K.H., Maity J.P. 2009. Geochemical characteristics of the fluids and muds from two southern Taiwan mud volcanoes: Implications for water sediment interaction and groundwater arsenic enrichment. Applied Geochemistry, 24(9):1793-1802. https://doi.org/10.1016/j.apgeochem.2009.06.002

18. Lagunova I.A., Gemp S.D. 1978. [Hydrogeochemical features of mud volcanoes]. Sovetskaya geologiya [Soviet geology], 8: 108-124. (In Russ.).

19. Lavrushin V.Y., Kikvadze O.E., Pokrovsky B.G., Polyak B.G., Guliev I.S., Aliev A.A. 2015. Waters from mud volcanoes of Azerbaijan: Isotopic-geochemical properties and generation environments. Lithology and Mineral Resources, 50(1): 1-25. https://doi.org/10.1134/S0024490215010034

20. Mazzini A., Etiope G. 2017. Mud volcanism: An updated review. Earth-Science Reviews, 168: 81-112. http://dx.doi.org/10.1016/j.earscirev.2017.03.001

21. Melnikov O.A., Ershov V.V. 2010. Mud (gas-water-lithoclastite) volcanism of the Sakhalin Island: History, results and prospects in research. Vestnik DVO RAN = Vestnik of the Far East Branch of RAS, 6: 87-93. (In Russ., abstract in Eng.).

22. Mel'nikov O.A., Il'yev A.Ya. 1989. [New mud volcanism manifestations on Sakhalin]. Tikhookeanskaya geologiya = Pacific Geology, 3: 42-49. (In Russ.).

23. Mel'nikov O.A., Ershov V.V., Ung K.C., Se S.R. 2008. Dynamics of the gryphon activity of gas-water-lithoclastite (mud) volcanoes and their relation to the natural seismicity as exemplified by the Yuzhno-Sakhalinsk volcano (Sakhalin Island). Russian J. of Pacific Geology, 2(5): 397-411. 
24. Nikitenko O.A. 2019. [Carbonate system of mud volcanic waters as exemplified by the South Sakhalin mud volcano]. In.: Stroyeniye litosfery i geodinamika: Materialy XXVIII Vseros. molodezhnoy konf., 8-14 aprelya 2019, Irkutsk [Structure of lithosphere and geodynamics: Proceedings of the XXVII All-Russian conference for young researchers, April 8-14, 2019, Irkutsk]. Irkutsk: Institute of the Earth Crust SB RAS, 119-120. (In Russ.).

25. Nikitenko O.A., Ershov V.V. 2017. Global patterns in formations of isotopic composition $\left(\delta^{18} \mathrm{O}, \delta \mathrm{D}\right)$ of water from mud volcanoes. Vestnik KRAUNTs = Bulletin of KRAESC. Earth Sciences, 34(2), 49-60. (In Russ., abstract in Eng.).

26. Nikitenko O.A., Ershov V.V., Levin B.W. 2017. The first identification of hydrogeochemical indicators of mud volcanic activity. Doklady Earth Sciences, 477(2): 1445-1448. https://doi.org/10.1134/S1028334X17120170

27. Nikitenko O.A., Ershov V.V., Perstneva Yu.A., Bondarenko D.D., Baloglanov E.E., Abbasov O.R. 2018. Substance composition produced by mud volcanoes of Sakhalin Island and Azerbaijan: the first comparison. Geosistemy perehodnykh zon = Geosystems of Transition Zones, 2(3): 346-358. (In Russ., abstract in Eng.). https://doi.org/10.30730/2541-8912.2018.2.4.346-358

28. Ray S.J., Kumar A., Sudheer A.K., Deshpande R.D., Rao D.K., Patil D.J., Awasthi N., Bhutani R., Bhushan R., Dayal A.M. 2013. Origin of gases and water in mud volcanoes of Andaman accretionary prism: implications for fluid migration in forearcs. Chemical Geology, 347: 102-113.

29. Sakharov V.A., Ilin V.V., Morozova O.A., Vypryazhkin E.N., I Ken Khi, Gogoleva I.V. 2020. Daginsky deposit of thermal mineral waters. Formation conditions, current state, prospects for use (Sakhalin region). Izvestiya Tomskogo politekhnicheskogo universiteta. Inzhiniring georesursov = Bulletin of the Tomsk Polytechnic University. Geo Assets Engineering, 331(1): 13-26. (In Russ.). (https://doi.org/10.18799/24131830/2020/1/2443

30. Shakirov R.B., Syrbu N.S., Obzhirov A.I. 2012. Isotope and gas-geochemical features of methane and carbon dioxide distribution on Sakhalin Island and adjacent shelf of the Okhotsk Sea. Vestnik KRAUNTs = Bulletin of KRAESC. Earth Sciences, 2(20): 100-113. (In Russ., abstract in Eng.).

31. Shilov V.N., Zakharova M.A., Il'yev A.Ya., Podzorov A.V. 1961. [Eruption of the South Sakhalin mud volcano in the spring of 1959]. Trudy SakhKNII SO AN SSSR [Transactions of the Sakhalin Complex Scientific Research Institute SB AS of USSR], 10: 83-99. (In Russ.).

32. Shteyn M.A. 1962. [Determination of the parameters and depths of underground thermal water occurrence]. Trudy SakhKNII [Transactions of the Sakhalin Complex Scientific Research Institute], 12: 162-165. (In Russ.).

33. Shvartsev S.L. 1996. Obshchaya gidrogeologiya [General hydrogeology]. Moscow: Nedra, 423 p. (In Russ.).

34. Siryk I.M. 1968. Neftegazonosnost' vostochnykh sklonov Zapadno-Sakhalinskikh gor [Hydrocarbon potential of the eastern slopes of the Western Sakhalin mountains]. Moscow: Nauka, 248 p. (In Russ.).

35. Sokol E.V., Kokh S.N., Kozmenko O.A., Lavrushin V.Yu., Belogub E.V., Khvorov P.V., Kikvadze O.E. 2019. Boron in an onshore mud volcanic environment: Case study from the Kerch Peninsula, the Caucasus continental collision zone. Chemical Geology, 525: 58-81. https://doi.org/10.1016/j.chemgeo.2019.07.018

36. Sorochinskaya A.V., Shakirov R.B., Obzhirov A.I., Zarubina N.V., Karabtsov A.A. 2008. Gasgeochemical and mineralogical features of mud volcanoes on Sakhalin Island. Vestnik DVO RAN = Vestnik FEB RAS, 4: 58-65. (In Russ., abstract in Eng.).

37. Tsitenko N.D. 1961a. [Mud volcanoes in the Daginsky area of Sakhalin Island]. Trudy VNIGRI [Transactions of the All-Union Scientific Research Institute of Petroleum Geology], 181: 171-175. (In Russ.).

38. Tsitenko N.D. 1961b. [Waters of the Daginsky hot springs on the Island of Sakhalin (on the problem of formation of chemical composition of calcium chloride waters]. Trudy VNIGRI [Transactions of the All-Union Scientific Research Institute of Petroleum Geology], 181: 203-212. (In Russ.).

39. Veselov O.V., Soinov V.V. 1997. [Heat flow in Sakhalin and Southern Kuril Islands]. In.: Geodinamika tektonosfery zony sochleneniya Tikhogo okeana s Yevraziyey. T. 4. Struktura i veshchestvennyy sostav osadochnogo chekhla severo-zapada Tikhogo okeana [Geodynamics of tectonosphere in the suture zone of the Pacific Ocean and Eurasia. Vol. 4. Structure and material composition of the sedimentary cover in the north western of the Pacific Ocean]. Yuzhno-Sakhalinsk: IMGG FEB RAS, 153-176. (In Russ.).

40. Zharkov R.V. 2008. [Daginsky deposit of thermal mineral waters in the north of Sakhalin Island]. In.: Prirodnyye katastrofy: izucheniye, monitoring, prognoz: Sb. materialov II Sakhalinskoy molodezhnoy nauchnoy shkoly, 4-10 iyunya 2007, Yuzhno-Sakhalinsk [Natural catastrophes: study, monitoring, forecast: Proceedings of the II Sakhalin scientific school for young researchers, June 4-10, 2007, Yuzhno-Sakhalinsk]. Yuzhno-Sakhalinsk: IMGG FEB RAS, 285-290. (In Russ.).

41. Zharkov R.V. 2018. Modern physicochemical features of thermomineral waters of the Daginsky deposit (Sakhalin Island). Monitoring. Nauka i tekhnologii = Monitoring. Science and Technologies, 4(37): 35-40. (In Russ., abstract in Eng.). https://doi.org/10.25714/MNT.2018.37.004 